\title{
Vitamin D and Aspects of Cardiovascular Disease
}

Anna Deleskog ${ }^{1 *}$ and Claes-Goran Ostenson ${ }^{2}$

${ }^{1}$ Division of Epidemiology, Institute of Environmental Medicine, Karolinska Institute, Stockholm, Sweden

${ }^{2}$ Department of Molecular Medicine and Surgery, Karolinska Institute, Stockholm, Sweden

\begin{abstract}
Vitamin D deficiency is widely prevalent worldwide and is primarily caused by lack of ultraviolet $B$ (UVB) radiation from reduced sun exposure and the consequent limiting of vitamin D production in the skin. Epidemiological studies support the concept that vitamin $\mathrm{D}$ is involved in the pathogenesis of cardiovascular disease (CVD). There are several lines of evidence for a number of potential mechanisms whereby vitamin $D$ status may influence CVD risk. Vitamin D receptors (VDR) are known to be expressed in cells throughout the cardiovascular system. In addition, 1a-hydroxylase which converts 25 -hydroxyvitamin $D$ to calcitriol is produced in many cell types including vascular, smooth muscle cells, endothelial cells and cardiomyocytes. However, as reported in this review previous observational and vitamin $\mathrm{D}$ supplemental studies have shown conflicting results regarding vitamin $\mathrm{D}$ and $\mathrm{CVD}$.
\end{abstract}

Keywords: Cardiovascular disease; Vitamin D

\section{Introduction}

Vitamin D insufficiency affects almost $50 \%$ of the population worldwide [1]. The high prevalence of vitamin D insufficiency is an important public health issue, and vitamin $\mathrm{D}$ insufficiency is an independent risk factor for total mortality in the general population [2]. The main source of vitamin $\mathrm{D}$ is synthesis in the skin after exposure to sunlight. Some vitamin $\mathrm{D}$ also derives from the diet [1]. Both sources are metabolized in the liver to 25-hydroxyvitamin $\mathrm{D}(25(\mathrm{OH}) \mathrm{D})$ which is used to determine vitamin D status (Figure 1). This form of vitamin $\mathrm{D}$ is biologically inactive and must be converted in the kidney by the 1a-hydroxylase to the active form 1,25-dihydroxyvitamin D $(1,25(\mathrm{OH}) 2 \mathrm{D}$ or calcitriol) [3]. Many extra-renal tissues also express 1a-hydroxylase which can produce significant tissue levels of 1,25(OH)2D. Vitamin D receptors (VDRs) are present in most tissues and cells, among them pancreatic $\beta$-cells, skeletal muscle cells, cardiomyocytes, smooth muscle cells, vascular endothelial cells, neurons and immmune cells. The binding of $1,25(\mathrm{OH}) 2 \mathrm{D}$ to the VDR leads to transcription of genes that are directly or indirectly influenced by $1,25(\mathrm{OH}) 2 \mathrm{D}$. These genes control cellular proliferation, differentiation, and apoptosis as well as insulin, renin and cathelicidin production [3].

At extreme northern and southern latitudes, one major risk factor for vitamin D insufficiency is pigmented skin. Other risk factors are obesity, strict use of sunscreen or concealing clothes. Elderly and intitutionalised individuals are at risk because they spend large amount of time indoors and have reduced dermal capacity to generate vitamin $\mathrm{D}[4]$. There are also seasonal variations in circulating $25(\mathrm{OH}) \mathrm{D}$ levels, vitamin D concentrations being higher in summer than winter [1].

\section{Vitamin $\mathrm{D}$ and cardiovascular disease}

Laboratory experiments and epidemiological studies suggest a protective effect for vitamin $\mathrm{D}$ against CVD. There are several lines of evidence for a number of potential mechanisms whereby vitamin $\mathrm{D}$ status may influence CVD risk (Figure 2) [3]. The VDRs are expressed in cells throughout the vascular system. Many cell types including vascular smooth muscle cells, endothelial cells, and cardiomyocytes produce $1 \alpha$-hydroxylase and thus have potential for autocrine and paracrine production of $1,25(\mathrm{OH}) 2 \mathrm{D}$ [3]. This process may be involved in a wide range of physiological functions where $1,25(\mathrm{OH}) 2 \mathrm{D}$ has been shown to inhibit vascular smooth cell proliferation, regulate the renin-angiotensin system, decrease insulin resistance, decrease coagulation and exhibit anti-inflammatory properties [3]. Apart from a direct impact on cardiomyocytes and CVD, it has been suggested that 25(OH)D indirectly influences CVD by modifying cardiovascular risk factors like diabetes, obesity, cholesterol concentration, hypertension, and effects of smoking [5,6]. Thus, in the National Health and Nutrition Examination III survey, including 15,088 women and men, 20 years or older, the prevalences of hypertension, diabetes and

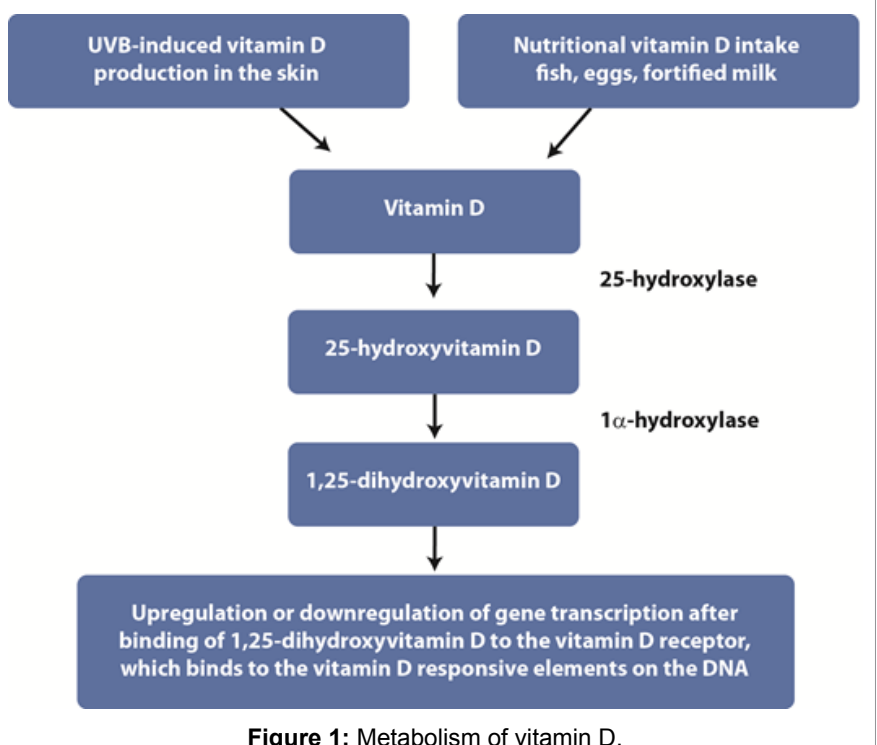

*Corresponding author: Anna Deleskog, MPH, PhD, Division of Epidemiology, Institute of Environmental Medicine, Karolinska Institute, SE-17177 Stockholm Sweden, Tel: +46-70-6173464 ; Fax: +46-8-31 11 01; E-mail: Anna.Deleskog@ki.se

Received April 01, 2015; Accepted May 04, 2015; Published May 07, 2015

Citation: Deleskog A, Ostenson CG (2015) Vitamin D and Aspects of Cardiovascular Disease. J Diabetes Metab 6: 545. doi:10.4172/2155-6156.1000545

Copyright: @ 2015 Deleskog A, et al. This is an open-access article distributed under the terms of the Creative Commons Attribution License, which permits unrestricted use, distribution, and reproduction in any medium, provided the original author and source are credited. 


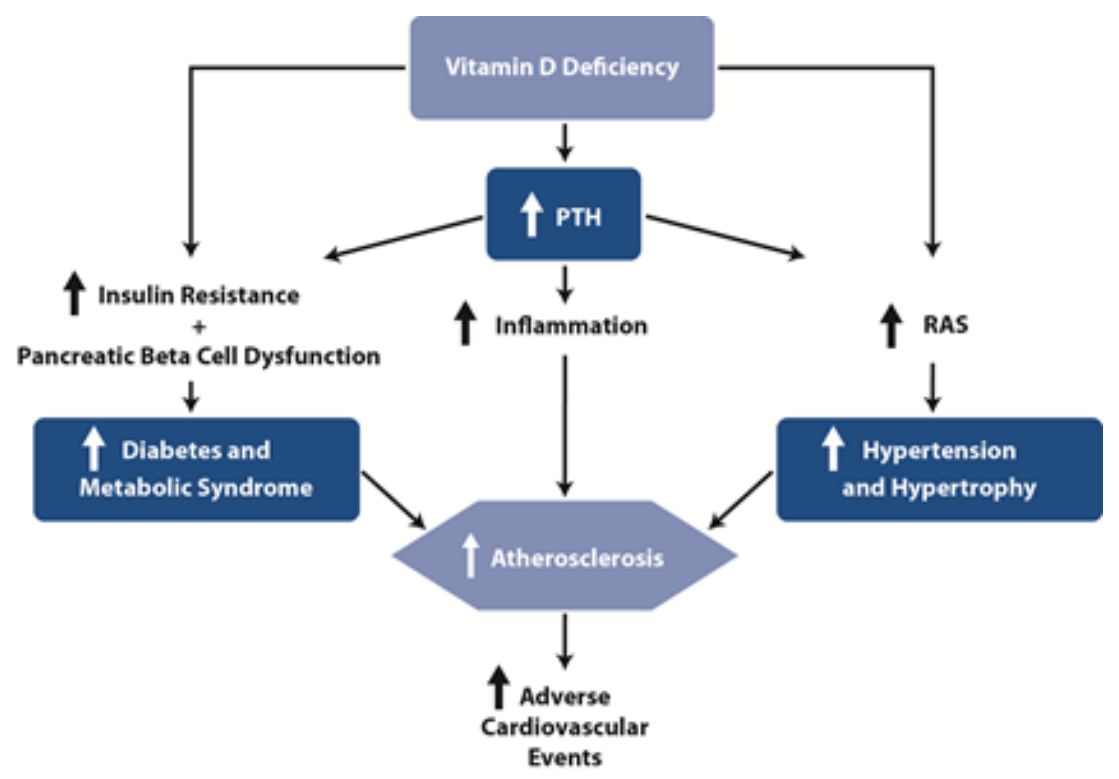

Figure 2: Potential mechanisms for the effects of insufficient vitamin D levels on CVD.

hypertriglyceridemia were significantly higher in those with the lowest concentration of $25(\mathrm{OH}) \mathrm{D}$ [5].

\section{Evidence from observational studies}

A meta-analysis comprising four studies of incident CVD and five independent mortality studies, and vitamin D deficiency, demonstrated a pooled HR of 1.54 and 1.83 respectively [7]. Participants in the incidence studies were initially healthy in contrast to studies on CVD mortality where the general population or patients with cardiovascular symptoms, or samples enriched for diabetes, were studied. The two largest incidence studies provided the strongest support for an association between vitamin D deficiency and incident CVD (fatal or non-fatal coronary heart disease or myocardial infarction). The Health Professional Follow-up Study exhibited 2-fold increased risk of myocardial infarction (MI) in vitamin D-deficient $(25(\mathrm{OH}) \mathrm{D}<$ $37.5 \mathrm{nmol} / \mathrm{L}$ ) subjects after 10 year follow-up [8]. In the Framingham Offspring Study, severe vitamin D deficiency $(<25 \mathrm{nmol} / \mathrm{L})$ was associated with a HR of 1.8 for first cardiovascular event after 5 year follow-up [6]. However, only 5 out of the 9 individual studies included in the meta-analysis reported a significantly increased risk in subjects with low serum 25(OH)D concentration [7]. Similar, the associations between vitamin $\mathrm{D}$ concentrations and arrhythmia (atrial fibrillation) and stroke have shown mixed results with no clear consensus [9].

The association between $25(\mathrm{OH}) \mathrm{D}$ levels and CVD risk may be nonlinear and reach a plateau between 50 to $70 \mathrm{nmol} / \mathrm{L}$ or U-shaped, with an increase in CVD risk at 25(OH)D levels both $<50$ and $>125$ $\mathrm{nmol} / \mathrm{L}$. The meta-analysis by Grandi et al. found that cardiovacular risk was increased in individuals with $25(\mathrm{OH}) \mathrm{D}$ levels below cut-off ranging from $25 \mathrm{nmol} / \mathrm{L}$ to $50 \mathrm{nmol} / \mathrm{L}$ [7]. In addition, a meta-analysis of prospective studies investigating vitamin $\mathrm{D}$ deficiency in relation to mortality reported a nonlinear decrease in mortality risk as circulating $25(\mathrm{OH}) \mathrm{D}$ increases, with optimal concentrations around 75-87.5 $\mathrm{nmol} / \mathrm{L}$ [10]. The data demonstrated a $31 \%$ reduction in mortality risk at levels between $75-87.5 \mathrm{nmol} / \mathrm{L}$ compared with concentrations of $27.5 \mathrm{nmol} / \mathrm{L}$. Some researchers consider $25(\mathrm{OH}) \mathrm{D}$ concentrations of $50 \mathrm{nmol} / \mathrm{L}$ to be adequate for bone and overall health in healthy individuals [11], while others have pointed out that advantageous serum concentrations start at the level of $75 \mathrm{nmol} / \mathrm{L}$ and that further improvement is achieved between 90 to $100 \mathrm{nmol} / \mathrm{L}$ [12].

A case-control study from our research group included a total of 387 survivors of a first MI before the age of 60 and 387 sex and agematched controls [13]. Fasting blood samples, drawn three months after MI in cases and at the same time in matched controls, were used for biochemical analyses. Low 25(OH)D levels were associated with a range of cardiovascular risk factors but were not related to MI. Among those risk factors, 25(OH)D concentrations were indepently associated with PAI-1 activity and pro-insulin levels [13]. PAI-1 is an inhibitor of plasminogen activation and constitutes an important regulatory protein in fibrinolysis. High plasma levels of PAI-1 have been shown to be associated with increased CVD [14]. High plasma proinsulin levels may indicate pancreatic $\beta$-cell stress, and deficient levels of $25(\mathrm{OH}) \mathrm{D}$ have been proposed to affect pancreatic $\beta$-cell dysfunction. Interestingly, there was also an inverse association of $25(\mathrm{OH}) \mathrm{D}$ levels with proinsulin, which suggests a connection with development of type 2 diabetes (T2D) and CVD.

The IMPROVE study is a multicentre, longitudinal cohort study that enrolled individuals aged 54 to 80 years, who had at least three cardiovascular risk factors and no history of CVD, from 7 centers in Finland, Sweden, the Netherlands, France, and Italy [15]. Participants underwent carotid ultrasound examinations at baseline, month 15 and month 30. Blood samples, clinical data and information about life-style factors were collected at baseline from a total of 3,711 subjects, whereof 900 with diabetes. The results demonstrated that levels of $25(\mathrm{OH}) \mathrm{D}$ differed across Europe and were not consistently and independently related to measures of carotid intima media thickness (cIMT) [15]. In the same study population, $25(\mathrm{OH}) \mathrm{D}$-associated genetic variants, serum $25(\mathrm{OH}) \mathrm{D}$ concentration and measures of cIMT in subjects with and without T2D were examined [16]. The results showed a significant association between the $25(\mathrm{OH}) \mathrm{D}$-decreasing allele of rs3829251 in the DHCR7 locus (gene involved in vitamin D metabolism which converts 7-dehydrocholesterol to cholesterol) and faster progression of cIMT, which depended on interaction with T2D status and was independent of 


\begin{tabular}{|c|c|c|c|}
\hline Incidence studies & $\begin{array}{l}\text { Follow-up } \\
\text { length }\end{array}$ & Country & Clinical endpoint \\
\hline Marniemi et al. [21] & 10 years & Finland & $\begin{array}{c}\text { Fatal/non-fatal coronary } \\
\text { events }\end{array}$ \\
\hline Giovannucci et al. [8] & 10 years & USA & $\begin{array}{l}\text { Fatal coronary heart disease } \\
\text { events and non-fatal MI }\end{array}$ \\
\hline Wang et al. [6] & 7.6 years & USA & $\begin{array}{l}\text { First fatal/non-fatal } \\
\text { cardiovascular events }\end{array}$ \\
\hline Bolland et al. [22] & 5 years & New Zealand & $\mathrm{MI}$ \\
\hline \multicolumn{4}{|c|}{ Mortality studies } \\
\hline Dobnig et al. [23] & 7.7 years & Germany & Cardiovascular death \\
\hline Melamed et al. [2] & 8.7 years & USA & Cardiovascular death \\
\hline Pilz et al. [24] & 6.2 years & Netherlands & Cardiovascular death \\
\hline Kilkkinen et al. [25] & 27.1 years & Finland & Cardiovascular death \\
\hline Semba et al. [26] & 6.5 years & Italy & Cardiovascular death \\
\hline
\end{tabular}

Table 1: Prospective studies assessing the association between $25 \mathrm{OHD}$ concentrations with incidence of cardiovascular events and mortality.

serum 25(OH)D levels and established cardiovascular risk factors [16]. These findings suggest that a pathway associated with the metabolism of vitamin $\mathrm{D}$ is causally implicated in subclinical atherosclerosis in subjects with T2D. However, the serum $25(\mathrm{OH}) \mathrm{D}$ concentration might be a poor reflection of vitamin $\mathrm{D}$ actions in target cells and tissues.

\section{Randomized clinical trials}

Two RCTs of vitamin D supplementation report a slight but nonstatistically significant reduction in CVD events $[17,18]$. Similarly, the Women's Health Initiative Calcium-Vitamin D trials, in which 36,282 women were randomized to calcium $1000 \mathrm{~g} / \mathrm{d}$ plus vitamin D $400 \mathrm{IU} /$ day or placebo for 7 years, found no reduction in CVD morbidity [19]. The median increase in $25(\mathrm{OH}) \mathrm{D}$ levels was however rather small, from $42.3 \mathrm{nmol} / \mathrm{L}$ to $54.1 \mathrm{nmol} / \mathrm{L}$. Supplementation with at least 1,000 IU/day would be required to attain $25(\mathrm{OH}) \mathrm{D}$ concentration above $75 \mathrm{nmol} / \mathrm{L}$ [12]. A recent meta-analysis including six RCTs assessing the effect of vitamin D supplementation on risk of MI showed nonsignificant pooled RR of 1.02 [20]. RCTs using higher vitamin D doses are required to determine whether vitamin $\mathrm{D}$ protects against coronary heart disease. Currently, there are two ongoing RCTs, expected to provide results within 2 years (the Vitamin D Assessment - ViDA and the Vitamin D and Omega-3 Trial - VITAL).

\section{Conclusion}

Experimental and epidemiological studies support that vitamin D exerts various positive effects on the cardiovascular system and associations between several cardiovascular risk factors. Moreover, meta-analysis of prospective studies suggests that a low level of $25(\mathrm{OH})$ $\mathrm{D}$ is an independent risk marker for future cardiovascular events and mortality (Table 1) [21-26]. In contrast, the results from RCTs on vitamin $\mathrm{D}$ treatment and cardiovascular risk are inconsistent and it is not possible to make definite conclusions regarding the effects of vitamin D on cardiovascular risk. Therefore larger RCTs with sufficient vitamin D doses to assess cardiovascular endpoints are warranted.

\section{References}

1. Holick MF (2007) Vitamin D deficiency. N Engl J Med 357: 266-281.

2. Melamed ML, Michos ED, Post W, Astor B (2008) 25-hydroxyvitamin D levels and the risk of mortality in the general population. Arch Intern Med 168: 16291637.

3. Pilz S, Tomaschitz A, Ritz E, Pieber TR (2009) Vitamin D status and arterial hypertension: a systematic review. Nat Rev Cardiol 6: 621-630.

4. Pearce SHS, Cheetham TD (2010) Diagnosis and management of vitamin d deficiency. Br Med J 340: 11
5. Martins D, Wolf M, Pan D, Zadshir A, Tareen N, et al (2007) Prevalence of cardiovascular risk factors and the serum levels of 25-hydroxyvitamin $D$ in the United States: data from the Third National Health and Nutrition Examination Survey. Arch Intern Med 167: 1159-1165.

6. Wang TJ, Pencina MJ, Booth SL, Jacques PF, Ingelsson E, et al. (2008) Vitamin $D$ deficiency and risk of cardiovascular disease. Circulation 117: 503-511.

7. Grandi NC, Breitling LP, Brenner H (2010) Vitamin D and cardiovascular disease: systematic review and meta-analysis of prospective studies. Prev Med 51: 228-233.

8. Giovannucci E, Liu Y, Hollis BW, Rimm EB (2008) 25-hydroxyvitamin D and risk of myocardial infarction in men: a prospective study. Arch Intern Med 168 : 1174-1180.

9. Thompson J, Nitiahpapand R, Bhatti P, Kourliouros A (2015) Vitamin D deficiency and atrial fibrillation. Int J Cardiol 184: 159-162.

10. Zittermann A, lodice S, Pilz S, Grant WB, Bagnardi V, et al. (2012) Vitamin $D$ deficiency and mortality risk in the general population: a meta-analysis of prospective cohort studies. Am J Clin Nutr 95: 91-100.

11. Ross AC, Taylor CL, Yaktine AL, Del Valle HB (2011) Dietary reference intakes for calcium and vitamin d. Washington (DC): National Academies Press (US)

12. Bischoff-Ferrari HA, Giovannucci E, Willett WC, Dietrich T, Dawson-Hughes B (2006) Estimation of optimal serum concentrations of 25-hydroxyvitamin d for multiple health outcomes. Am J Clin Nutr 84: 18-28.

13. Deleskog A, Piksasova O, Silveira A (2012) Serum 25-hydroxyvitamin d concentration, established and emerging cardiovascular risk factors and risk of myocardial infarction before the age of 60 years. Atherosclerosis 223: 223-29.

14. Hamsten A, Defaire U, Walldius G (1987) Plaminogen-activator inhibitor in plasma - risk factor for recurrent myocardial infarction. Lancet 2: 3-8.

15. Deleskog A, Piksasova O, Ostenson CG (2012) Serum 25-hydroxyvitamin d relationships to carotid intima-media thickness (cimt) and cimt progression in a european high-risk population. Eur Heart J 33: 509-09.

16. Strawbridge RJ, Deleskog A, McLeod O (2014) A serum 25-hydroxyvitamin concentration-associated genetic variant in dhcr7 interacts with type 2 diabetes status to influence subclinical atherosclerosis (measured by carotid intimamedia thickness). Diabetologia 57:1159-72.

17. Trivedi DP, Doll R, Khaw KT (2003) Effect of four monthly oral vitamin d-3 (cholecalciferol) supplementation on fractures and mortality in men and women living in the community: Randomised double blind controlled trial. $\mathrm{Br}$ Med J 326: 469-72.

18. Prince RL, Austin N, Devine A, Dick IM, Bruce D, et al. (2008) Effects of ergocalciferol added to calcium on the risk of falls in elderly high-risk women. Arch Intern Med 168: 103-08.

19. Hsia J, Heiss G, Ren H (2007) Calcium/vitamin d supplementation and cardiovascular events. Circulation 115: 846-54.

20. Elamin MB, Abu Elnour NO, Elamin KB (2011) Vitamin d and cardiovascula outcomes: A systematic review and meta-analysis. J Clin Endocrinol Metab 96: 1931-42.

21. Marniemi J, Alanen E, Impivaara O (2005) Dietary and serum vitamins and minerals as predictors of myocardial infarction and stroke in elderly subjects. Nutrition Metabolism and Cardiovascular Diseases 15: 188-97.

22. Bolland MJ, Bacon CJ, Horne AM (2010) Vitamin d insufficiency and health outcomes over 5 y in older women. Am J Clin Nutr 91: 82-89.

23. Dobnig H, Pilz S, Scharnagl H (2008) Independent association of low serum 25-hydroxyvitamin $d$ and 1,25-dihydroxyvitamin d levels with all-cause and cardiovascular mortality. Arch Intern Med 168: 1340-49.

24. Pilz S, Dobnig H, Nijpels G (2009) Vitamin d and mortality in older men and women. Clin Endocrinol (Oxf) 71: 666-72.

25. Kilkkinen A, Knekt $P$, Aro A (2009) Vitamin d status and the risk of cardiovascular disease death. Am J Epidemiol 170: 1032-39.

26. Semba RD, Houston DK, Bandinelli S (2010) Relationship of 25-hydroxyvitamin $\mathrm{d}$ with all-cause and cardiovascular disease mortality in older communitydwelling adults. Eur J Clin Nutr 64: 203-09. 